\title{
Downregulation of PDCD4 induced by progesterone is mediated by the PI3K/AKT signaling pathway in human endometrial cancer cells
}

\author{
XISHUANG WANG ${ }^{1 *}$, YUE LI $^{1 *}$, LU WAN $^{1}$, YANPING LIU $^{2}$, YINGSHUO SUN ${ }^{2}$, \\ YUQIU LIU $^{2}$, YONGYU SHI ${ }^{1}$, LINING ZHANG ${ }^{1}$, HUAIYU ZHOU ${ }^{3}$, \\ JIANING WANG ${ }^{1}$, XIAOYAN WANG ${ }^{1}$ and ZENGTAO WEI ${ }^{1,2,4}$
}

\begin{abstract}
${ }^{1}$ Department of Immunology, School of Basic Medical Sciences, Shandong University, Jinan, Shandong 250012;
${ }^{2}$ Department of Gynecology and Obstetrics, Jinan Central Hospital Affiliated to Shandong University, Jinan, Shandong 250013; ${ }^{3}$ Department of Microbiology, School of Basic Medical Sciences, Shandong University; ${ }^{4}$ Department of Gynecology and Obstetrics, Clinical Medical School, Jinan, Shandong 250012, P.R. China
\end{abstract}

Received August 26, 2018; Accepted June 7, 2019

DOI: $10.3892 /$ or.2019.7202

\begin{abstract}
Programmed cell death 4 (PDCD4) has been identified as a tumor-suppressor gene that inhibits neoplastic transformation, tumor progression, and protein translation. It has been reported that multiple factors participate in the regulation of PDCD $4 \mathrm{mRNA}$ and protein. The endometrium is regulated by changing concentrations of ovarian hormones, such as estrogen and progesterone, and shows periodical changes. However, whether ovarian hormones regulate PDCD4 expression remains unclear. This study aimed to explore the effect and mechanism of estrogen or progesterone on PDCD4 mRNA and protein expression in human endometrial cancer cells. The expression of PDCD4 mRNA and protein in Ishikawa and HEC-1-A cells was detected by quantitative real-time PCR and western blot analysis. The signaling pathway-related proteins were detected by western blot analysis. The results showed that PDCD 4 mRNA levels exhibited no significant changes after treatment with estrogen or progesterone in both Ishikawa and HEC-1-A cell lines. Estrogen also had no obvious effect on PDCD4 protein expression. However, progesterone effectively decreased the expression of PDCD4 protein and the PI3K/AKT pathway may be involved in the downregulation of PDCD4 protein induced
\end{abstract}

Correspondence to: Dr Zengtao Wei or Dr Xiaoyan Wang, Department of Immunology, School of Basic Medical Sciences, Shandong University, 44 Wenhua Xi Road, Jinan, Shandong 250012, P.R. China

E-mail: weizengtao1970@163.com; weizengtao@sdu.edu.cn

E-mail: wxy990809@163.com; wxy1970@sdu.edu.cn

${ }^{*}$ Contributed equally

Key words: PDCD4, progesterone, estrogen, endometrial cancer, PI3K/AKT by progesterone. These results suggest that the downregulation of PDCD4 induced by progesterone affects the therapeutic efficacy of progesterone in human endometrial cancer or endometriosis, which may have important implications for progesterone treatment in the clinic.

\section{Introduction}

Programmed cell death 4 (PDCD4) is an apoptosis-related gene. It is currently identified as a tumor-suppressor gene that inhibits neoplastic transformation $(1,2)$, tumor progression (3) and protein translation (4). PDCD4 is expressed ubiquitously in different normal tissues, especially the liver (5). However, the expression of PDCD4 in various types of cancers, such as liver cancer (6), lung cancer (7), breast cancer (8), is lost or decreased. We also found that the expression of PDCD4 is downregulated in ovarian cancer tissues compared with control ovarian epithelial tissues (9). It has been reported that multiple factors participate in the regulation of $P D C D 4$ mRNA and protein. $P D C D 4$ was first identified as an upregulated gene during apoptosis (5). Different pro-apoptotic substances, including ionomycin, phorbol-12-myristate-13-acetate (PMA) or dexamethasone, were found to induce increased levels of PDCD4 (10), but other inducers of apoptosis such as arabinosyl cytosine (ara-C), UV irradiation or topoisomerase inhibitors had no effect on the expression of PDCD4 $(11,12)$. Similarly, the levels of PDCD4 were found to be induced by interleukin (IL)-12, but decreased by IL-2 and IL-15 treatment (13). These results suggest that the expression of PDCD4 may vary depending on different stimuli (11).

The endometrium is regulated by changing concentrations of ovarian hormones, such as estrogen and progesterone, and shows periodical changes, including proliferative phase, secretory phase and menstrual phase. Estrogen is increased in the proliferative phase of the endometrium; after ovulation progesterone is produced and drives the endometrium into a secretory phase. When the levels of estrogen and progesterone are decreased, the endometrium enters into a 
menstrual phase. Therefore, the levels of ovarian hormones during the menstrual cycle are changed. It has been reported that ovarian hormones affect the expression of many genes, such as catalase (14) and IL-10R (15), and further induce gene expression variation during the cycle changes of the endometrium. Ovarian hormones not only regulate gene transcription by directly or indirectly binding to DNA, but also regulate gene expression by binding to corresponding membrane receptors and further initiate various signaling pathways, including mitogen-activated protein kinase/extracellular regulated protein kinase (MAPK/ERK) and phosphatidylinositol 3-kinase/protein kinase B (PI3K/AKT) pathways (16). In a previous study, we found that the expression of PDCD4 in the proliferative phase of the endometrium was higher than that in the secretory phase of the endometrium (17). This suggests that the expression of PDCD4 may be regulated by ovarian hormones. However, the effect and mechanism of ovarian hormones on the expression of PDCD4 remain unclear.

In the present study, we aimed to investigate whether PDCD4 expression is regulated by estrogen and progesterone via the MAPK/ERK or PI3K/AKT pathways, and it was confirmed that progesterone could downregulate the expression of PDCD4 protein via PI3K/AKT pathway.

\section{Materials and methods}

Primary antibodies. Rabbit polyclonal or monoclonal antibodies specific for PDCD4 (cat. no. cst-9535S); MAPK signaling pathway-related molecules: Stress-activated protein kinase/Jun-amino-terminal kinase (SAPK/JNK) (cat. no. cst-9252), p44/42MAPK (ERK1/2) (cat. no. cst-4695), p38MAPK (cat. no. cst-8690); PI3K/AKT signaling pathway-related molecules: AKT (cat. no. cst-4691), mammalian target of rapamycin (mTOR) (cat. no. cst-2983), as well as phospho-SAPK/JNK (phosphorylation site: Thr183/Tyr185) (cat. no. cst-4668), phospho-p44/42 MAPK (ERK1/2) (phosphorylation site: Thr202/Tyr204) (cat. no. cst-4370), phospho-p38MAPK (phosphorylation site: Thr180/Tyr182) (cat. no. cst-4511), phospho-AKT (phosphorylation site: Ser473) (cat. no. cst-4060), phospho-mTOR (phosphorylation site: Ser2448) (cat. no. cst-5536) were purchased from Cell Signaling Technology. Mouse monoclonal antibody specific for $\beta$-actin (TA-09; ZSGB-Bio, Beijing, China) was used as a loading control.

Cell culture. Well-differentiated human endometrial cancer Ishikawa cells were kindly provided by Qilu Hospital. The cells were cultured in Dulbecco's modified Eagle's medium (DMEM)-High Glucose medium (Hyclone) containing $10 \%$ fetal bovine serum (Gibco; Thermo Fisher Scientific, Inc.), penicillin and streptomycin (100X, MACGENE). Moderately differentiated endometrial cancer HEC-1-A cells were obtained from the China Center for Type Culture Collection (Wuhan, China). The cells were cultured in McCoy's 5A medium (Gibco; Thermo Fisher Scientific, Inc.) supplemented with $10 \%$ fetal bovine serum, penicillin and streptomycin. All the cells were incubated in a humidified atmosphere with $5 \% \mathrm{CO}_{2}$ at $37^{\circ} \mathrm{C}$.

Hormone treatments. The cells were respectively treated with $0,0.1,1,10,100$ and $1,000 \mathrm{nM}$ of $17 \beta$-estradiol (E2)
(Sigma-Aldrich; Merck KGaA) or 0, 0.01, 0.1, 1, 10 and $20 \mu \mathrm{M}$ of progesterone (P4) (Sigma-Aldrich; Merck KGaA). All treated cells were collected to detect the expression of PDCD4 mRNA or protein by quantitative real-time PCR (qPCR) or western blot analysis. The cells were treated with $10 \mu \mathrm{M}$ of progesterone for $0,6,12,24,36$ and $48 \mathrm{~h}$ to determine the time when progesterone begins to reduce the expression of PDCD4.

In order to investigate the signal transduction pathway which was involved in PDCD4 down-regulation induced by progesterone, the cells were firstly treated with $10 \mu \mathrm{M}$ of progesterone for $0,1,2$ and $4 \mathrm{~h}$, and the expression of signaling molecules was detected by western blot analysis. In addition, the cells were respectively pretreated with dimethyl sulfoxide (DMSO) and $5 \mu \mathrm{M}$ (18) of PI3K inhibitor LY294002 (Selleckchem) for $1 \mathrm{~h}$ or $100 \mathrm{nM}$ (19) of AKT inhibitor MK2206 (MedChem Express) for $2 \mathrm{~h}$, and then the cells were treated with $10 \mu \mathrm{M}$ of progesterone for $4 \mathrm{~h}$. All treated cells were collected to detect the expression of PDCD4 protein and signaling molecules.

RNA isolation and $q P C R$. Total RNA was extracted using RNAfast 200 (Fastagen) according to the manufacturer's protocol, and then reversely transcribed into complementary DNA using Reverse Transcription System (Takara). The expression levels of genes were assessed by qPCR using a $2 X$ UltraSYBR Mixture and specific primers (CWBIO) according to the manufacturer's instructions. qPCR was carried out using the Applied Biosystems STEP One Plus Real-Time PCR System (Applied Biosystems; Thermo Fisher Scientific, Inc.). The primers for PDCD4 were as follows: forward, CCTGGAAGATGGTGATGGGAT and reverse, AACGGA TTTGGTCGTATTGGG. Glyceraldehyde-3-phosphate dehydrogenase $(G A P D H)$ was used for an internal control to analyze $P D C D 4$ expression. The primers for $G A P D H$ were as follows: Forward: ACAGGTGTATGATGTGGAGGA and reverse, TTCTCAAATGCCCTTTCATCCAA. The qPCR Protocol was as follows: Pre-denaturation at $95^{\circ} \mathrm{C}$ for $10 \mathrm{~min}$, followed by 40 cycles with denaturation at $95^{\circ} \mathrm{C}$ for $15 \mathrm{sec}$ and annealing/elongation at $60^{\circ} \mathrm{C}$ for $1 \mathrm{~min}$. The expression of $P D C D 4$ was analyzed according to the comparative quantitative method $\left(2^{-\Delta \Delta \mathrm{Cq}}\right)$ and the samples were examined in triplicate.

Total protein extraction and western blot analysis. The cells were lysed using radio-immunoprecipitation assay (RIPA) lysis buffer (Beyotime) with protease inhibitor and phosphatase inhibitor (Bimake). After homogenization, the cells were centrifuged at $13,700 \mathrm{x} \mathrm{g}$ at $4^{\circ} \mathrm{C}$ for $30 \mathrm{~min}$. The supernatant was quantified using the bicinchoninic acid (BCA) assay kit (Thermo Fisher Scientific, Inc.) according to the manufacturer's instructions. Equal amounts of proteins were separated by sodium dodecyl sulfate (SDS) polyacrylamide gel, and then transferred onto polyvinylidene fluoride (PVDF) membranes (Millipore). After being blocked with 5\% bovine serum albumin (Sigma-Aldrich; Merck KGaA) in Tris-buffered saline Tween-20 (TBST) for 2 3 h. The membranes were respectively incubated overnight at $4{ }^{\circ} \mathrm{C}$ with a $1: 1,000$ dilution of primary antibodies. Next day, the membranes were incubated with a 1:2,000 dilution of horseradish peroxidase-conjugated secondary antibodies (Jackson Immuno Research) at room 
A

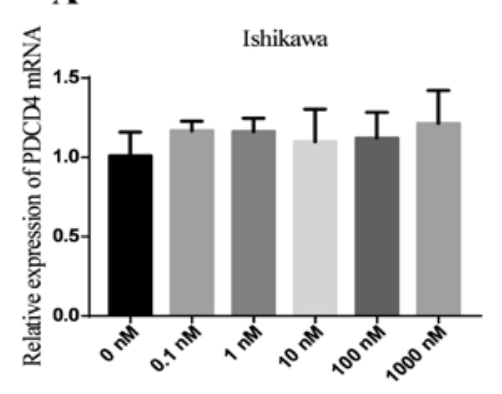

17ק-estradiol

C

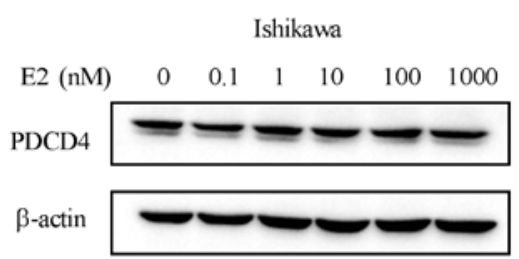

E

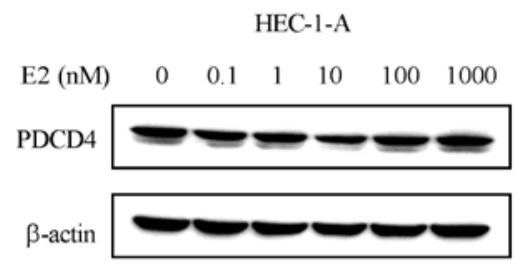

B

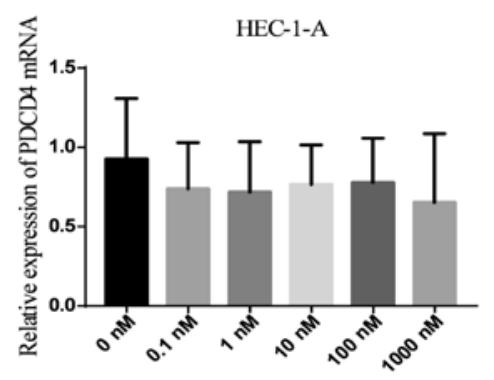

$17 \beta$-estradiol

D

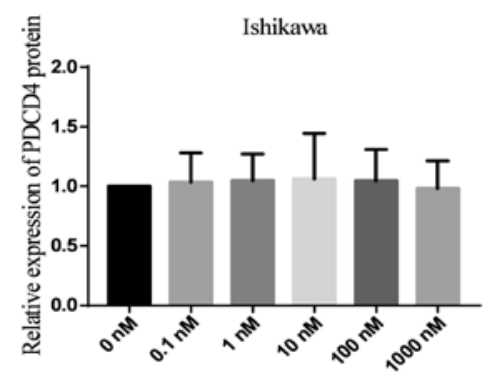

$17 \beta$-estradiol

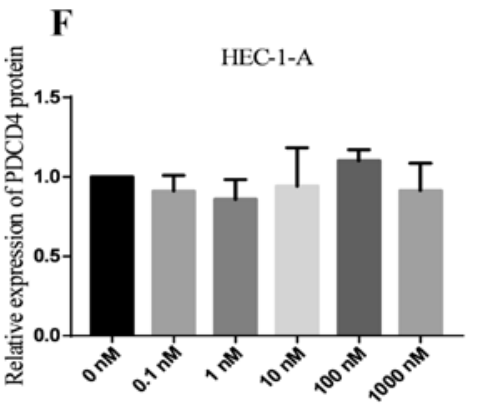

$17 \beta$-estradiol

Figure 1. Effect of estrogen on the expression of PDCD4 in human endometrial cancer cell lines. The results of qPCR showed that 17ß-estradiol (E2) had no effect on the expression of PDCD4 mRNA in (A) Ishikawa (P>0.05) and (B) HEC-1-A cells ( $\mathrm{P}>0.05)$. (C and $\mathrm{D})$ The level of PDCD4 protein was detected by western blot analysis after treatment with $17 \beta$-estradiol (E2) in Ishikawa cells and no significant difference in the expression of PDCD4 protein was noted $(\mathrm{P}>0.05)$. (E and F) The level of PDCD4 protein was detected by western blot analysis after treated with 17ß-estradiol (E2) in HEC-1-A cells and no significant difference in the expression of PDCD4 protein was noted (P>0.05). PDCD4, programmed cell death 4.

temperature for $1 \mathrm{~h}$. The signal was detected using the enhanced chemiluminescence kit (Millipore). $\beta$-actin was used as an internal reference for normalization of PDCD4. Total protein of mTOR, AKT, ERK1/2, P38, JNK1/2 were used as loading control for normalization of their phosphorylated protein levels.

Statistical analysis. Statistical analysis was performed with GraphPad Prism 7.0 software (GraphPad Software, Inc.). All data are presented as means \pm SD. A Dunnett's post hoc test after one way ANOVA was used to compared different test groups with one control group. The Student's t-test was performed to evaluate the statistical significance between two groups. $\mathrm{P}<0.05$ was considered to indicate a statistically significant difference.

\section{Results}

Effect of estrogen on the expression of PDCD4 in human endometrial cancer cell lines. After Ishikawa and HEC-1-A cells were treated with different concentrations of $17 \beta$-estradiol (E2) for $24 \mathrm{~h}, \mathrm{qPCR}$ was used to detect the expression of PDCD4 mRNA (Fig. 1A and B). After the above two cell lines were treated with different concentrations of $17 \beta$-estradiol (E2) for $48 \mathrm{~h}$, western blot analysis was performed to detect PDCD4 protein expression (Fig. 1C-F). The results showed that for any concentration of $17 \beta$-estradiol no effect on the expression of PDCD 4 mRNA and protein in the two types of cell lines was observed ( $\mathrm{P}>0.05)$ (Fig. 1).

Effect of progesterone on the expression of PDCD4 in human endometrial cancer cell lines. The effect of different concentrations of progesterone on PDCD4 mRNA expression was determined in Ishikawa and HEC-1-A cells. The results showed that at any concentration of progesterone no significant effect on the expression of PDCD4 mRNA was observed in the Ishikawa and HEC-1-A cells (Fig. 2A and B). Furthermore, an experiment of the time kinetic investigation on the PDCD4 mRNA level in Ishikawa and HEC-1-A cells was conducted. The results confirmed that progesterone failed to regulate the expression of 
A

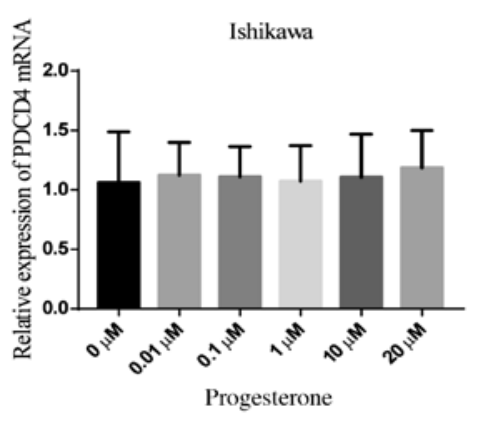

C

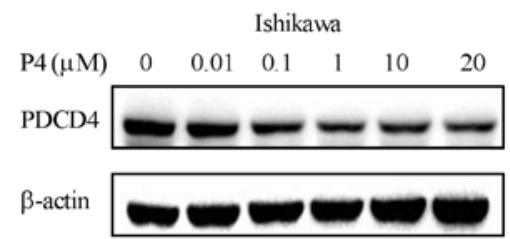

E

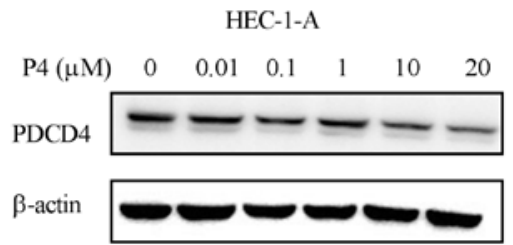

B

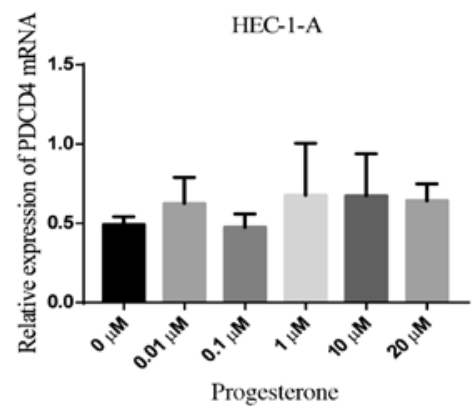

D

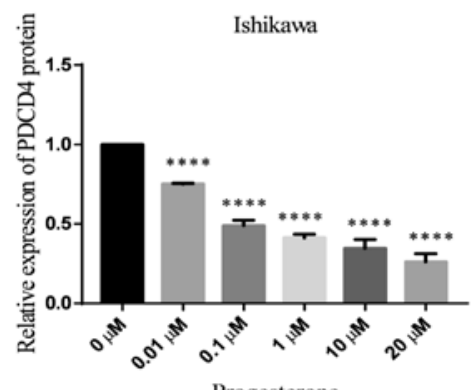

$\mathbf{F}$

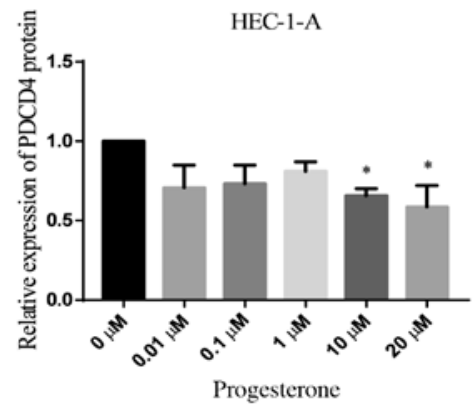

Figure 2. Effect of progesterone on the expression of PDCD4 in human endometrial cancer cell lines. The results of qPCR showed that progesterone had no any effect on the expression of PDCD4 mRNA in (A) Ishikawa (P>0.05) and (B) HEC-1-A cells (P>0.05). (C) The expression of PDCD4 protein was detected by western blot analysis after treatment with progesterone (P4) in Ishikawa cells and (D) expression of PDCD4 protein was significantly lower after treatment with different concentrations $(0,0.01,0.1,1,10$ and $20 \mu \mathrm{M})$ of progesterone in Ishikawa cells $\left({ }^{* * * *} \mathrm{P}<0.0001\right.$ vs. $\left.0 \mu \mathrm{M}\right)$. (E) The expression of PDCD4 protein was detected by western blot analysis after treatment with progesterone (P4) in HEC-1-A cells and (F) expression of PDCD4 protein was significantly lower after treatment with 10 and $20 \mu \mathrm{M}$ of progesterone in HEC-1-A cells $\left({ }^{*} \mathrm{P}<0.05\right.$ vs. $\left.0 \mu \mathrm{M}\right)$. PDCD4, programmed cell death 4.

PDCD4 at the mRNA level (data not shown). Then, the effect of different concentrations of progesterone on PDCD4 protein expression was investigated in Ishikawa and HEC-1-A cells. The results showed that different concentrations $(0.01,0.1,1$, 10 and $20 \mu \mathrm{M})$ of progesterone obviously downregulated the expression of PDCD4 protein in Ishikawa cells $(\mathrm{P}<0.0001$ vs. $0 \mu \mathrm{M}$ ) (Fig. 2C and D); however, only 10 and $20 \mu \mathrm{M}$ of progesterone effectively reduced the expression of PDCD4 protein in HEC-1-A cells $(\mathrm{P}<0.05$ vs. $0 \mu \mathrm{M})$ (Fig. $2 \mathrm{E}$ and $\mathrm{F})$. Next, we detected the effect of progesterone $(10 \mu \mathrm{M})$ on the PDCD4 protein expression at different time points in Ishikawa and HEC-1-A cells. It was found that PDCD4 protein began to decrease after progesterone treatment for $6 \mathrm{~h}$ in Ishikawa cells $(\mathrm{P}<0.01$ vs. $0 \mathrm{~h}$ ) (Fig. 3A and B). In HEC-1-A cells, the expression of PDCD4 protein started to decrease after progesterone treatment for $12 \mathrm{~h}(\mathrm{P}<0.05$ vs. $0 \mathrm{~h})$ (Fig. $3 \mathrm{C}$ and $\mathrm{D})$.

Progesterone activates the PI3K/AKT/mTOR pathway but not the MAPK pathway. We further determined whether the PI3K/AKT/mTOR pathway participates in the effect of progesterone on PDCD4 protein expression using $10 \mu \mathrm{M}$ of progesterone to treat Ishikawa and HEC-1-A cells for $0,1,2$ and $4 \mathrm{~h}$. It was found that the expression of $\mathrm{p}-\mathrm{mTOR}(\mathrm{P}<0.05$ vs. $0 \mathrm{~h}$ ) and p-AKT ( $\mathrm{P}<0.01$ vs. $0 \mathrm{~h})$ was significantly higher after treatment with progesterone (P4) for $4 \mathrm{~h}$ (Fig. 4A-C). In order to investigate whether the MAPK signaling pathway participates in the downregulation of PDCD4 protein expression induced by progesterone (P4), the expression of $\mathrm{p}-\mathrm{ERK} 1 / 2$, p-P38 and p-JNK was detected. It was found that the levels of p-ERK1/2, p-P38 and p-JNK had no significant changes following progesterone ( $\mathrm{P} 4)$ treatment $(\mathrm{P}>0.05)$ (Fig. 4D-F).

The PI3K/AKT pathway participates in the reduction of PDCD4 protein expression induced by progesterone. In order to confirm that progesterone (P4) downregulates the expression of PDCD4 protein via the PI3K/AKT pathway in Ishikawa and HEC-1-A cells, we used a PI3K inhibitor (LY294002) to pretreat Ishikawa and HEC-1-A cells for $1 \mathrm{~h}$ (Fig. 5A-C) or 
A

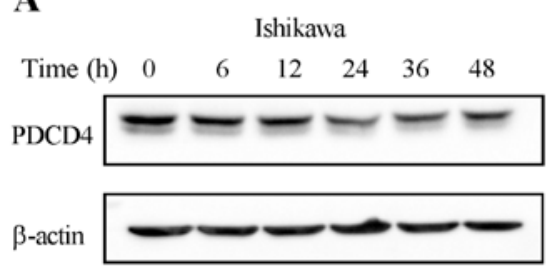

C

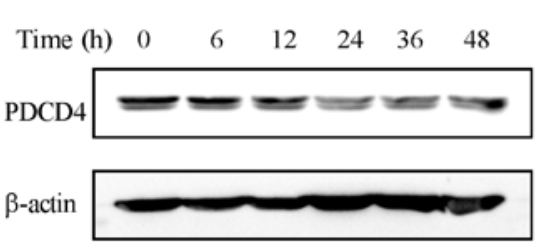

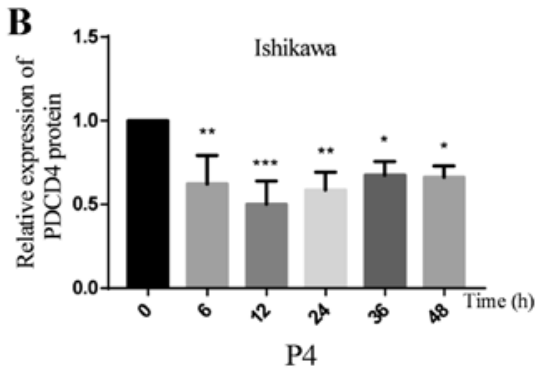

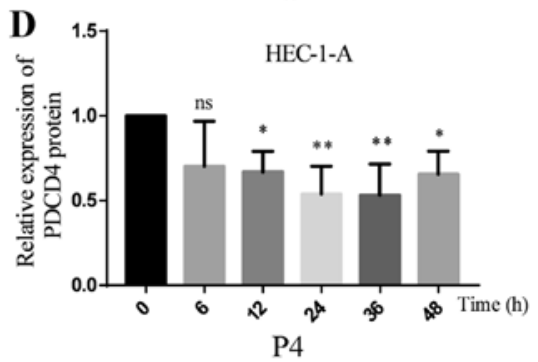

Figure 3. Effect of progesterone on the expression of PDCD4 protein at different time points. (A) The expression of PDCD4 protein was detected by western blot analysis in Ishikawa cells after treatment with $10 \mu \mathrm{M}$ of progesterone at different time points $(0,6,12,24,36$ and $48 \mathrm{~h})$. (B) The expression of PDCD4 protein began to decrease after progesterone treatment for $6 \mathrm{~h}$ in Ishikawa cells $\left(" \mathrm{P}<0.05\right.$ vs. $0 \mathrm{~h} ;{ }^{* * *} \mathrm{P}<0.01 \mathrm{vs} .0 \mathrm{~h}$; ${ }^{* * * *} \mathrm{P}<0.01$ vs. $\left.0 \mathrm{~h}\right)$. (C) The expression of PDCD4 protein was detected by western blot analysis in HEC-1-A cells after treatment with $10 \mu \mathrm{M}$ of progesterone at different time points $(0,6,12,24,36$ and $48 \mathrm{~h}$ ). (D) The expression of PDCD4 protein started to decrease after progesterone treatment for $12 \mathrm{~h}$ in HEC-1-A cells $\left({ }^{*} \mathrm{P}<0.05 \mathrm{vs} .0 \mathrm{~h}\right.$; ${ }^{* * *} \mathrm{P}<0.01 \mathrm{vs} .0 \mathrm{~h}$; ns, not significant). PDCD4, programmed cell death 4.

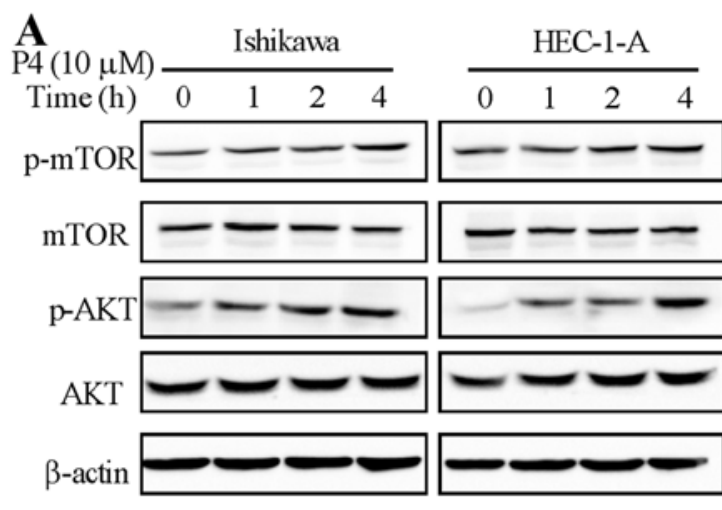

D

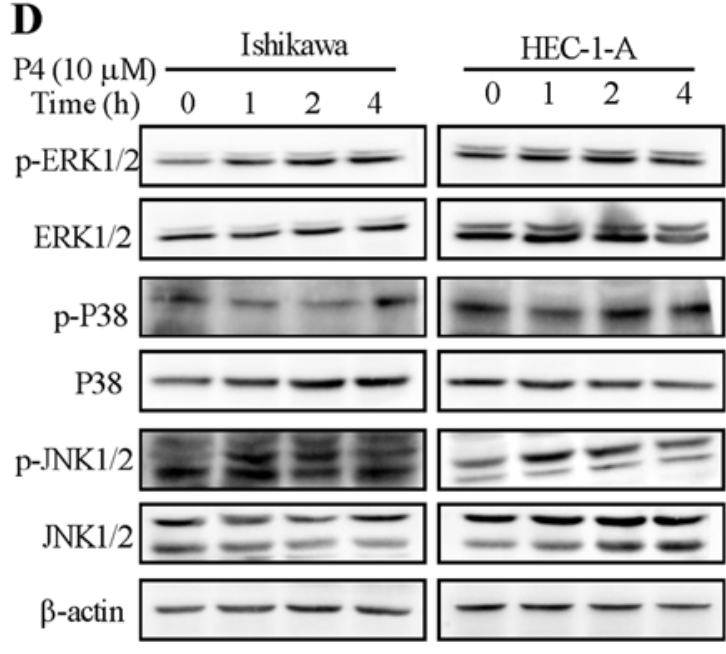

B

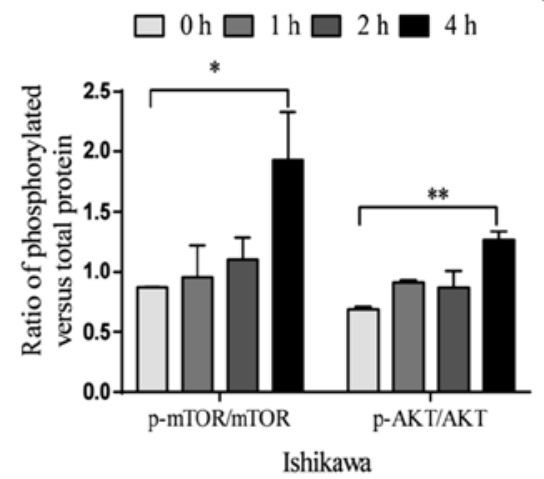

$\mathbf{E}$

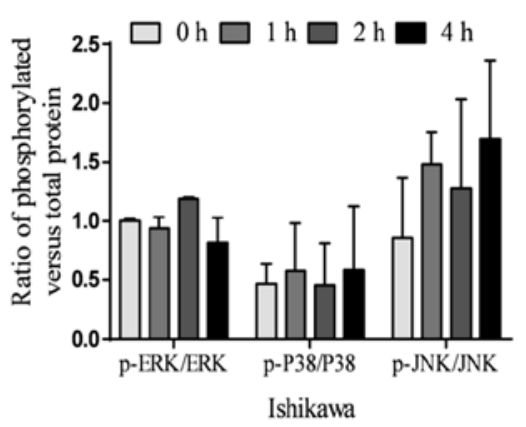

C

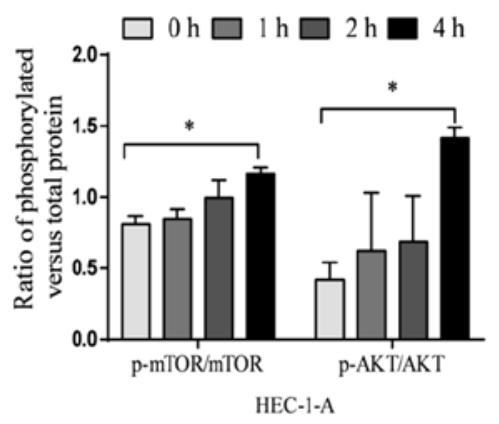

$\mathbf{F}$

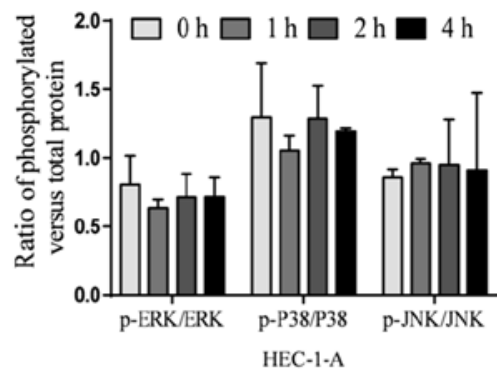

Figure 4. Effect of progesterone on the expression of signaling molecules in the PI3K/AKT/mTOR and MAPK pathways. (A) The expression of phosphorylated (p)-mTOR, mTOR, p-AKT, AKT and $\beta$-actin was detected by western blot analysis after treatment with $10 \mu \mathrm{M}$ of progesterone (P4) at different time points $(0$, 1,2 and $4 \mathrm{~h}$ ). Quantitative analysis of the ratios of p-mTOR/mTOR and p-AKT/AKT by measuring the relative band density in (B) Ishikawa and (C) HEC-1-A cells. (D) The expression of p-ERK, ERK, p-P38, P38, p-JNK, JNK and $\beta$-actin was detected by western blot analysis after treatment with $10 \mu \mathrm{M}$ of progesterone (P4) at different time points ( $0,1,2$ and $4 \mathrm{~h}$ ). (E) Quantitative analysis of the ratios of p-ERK/ERK, p-P38/P38 and p-JNK/JNK by measuring the relative band density in (E) Ishikawa and (F) HEC-1-A cells. " $\mathrm{P}<0.05$ vs. $0 \mathrm{~h} ;{ }^{* *} \mathrm{P}<0.01$ vs. $0 \mathrm{~h}$. 

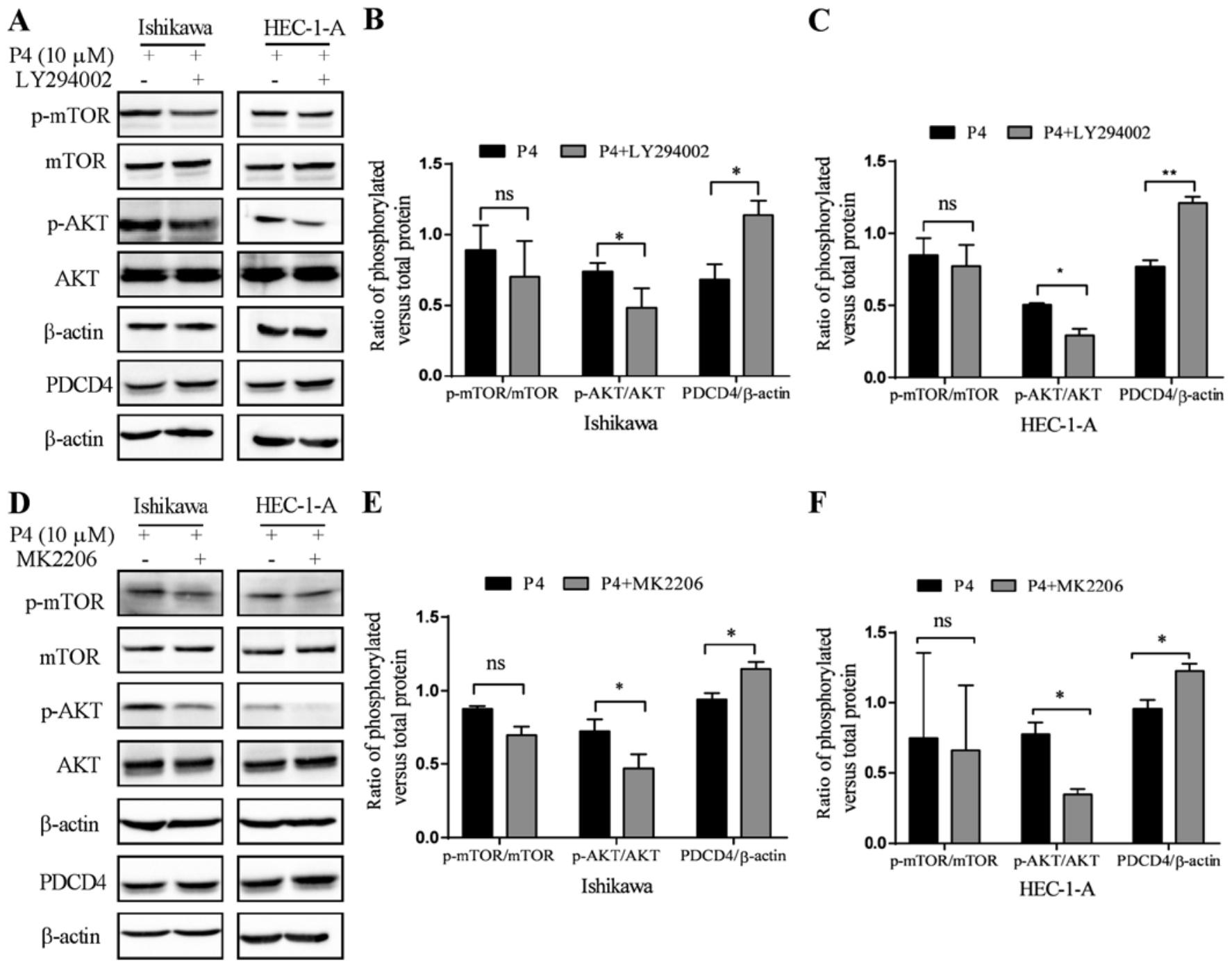

$\mathbf{F}$

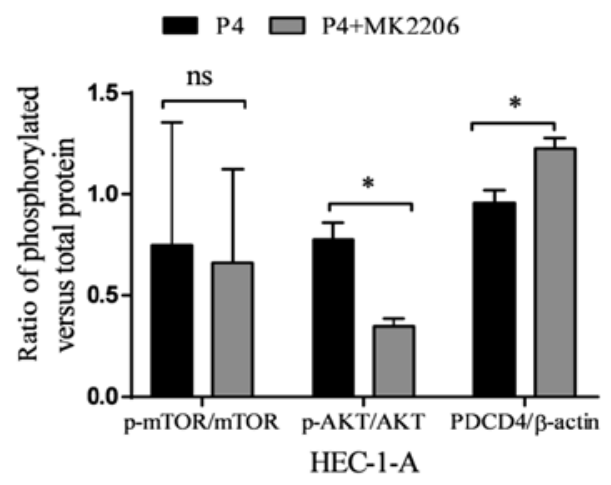

Figure 5. The PI3K/AKT pathway participates in the downregulation of PDCD4 protein expression induced by progesterone. (A) The effect of LY294002 (PI3K inhibitor) on the expression of phosphorylated (p)-mTOR, mTOR, p-AKT, AKT, PDCD4 and $\beta$-actin in Ishikawa and HEC-1-A cells. Cells were pre-treated with $5 \mu \mathrm{M}$ of LY294002 for $2 \mathrm{~h}$, and then treated with $10 \mu \mathrm{M}$ of progesterone (P4) for $4 \mathrm{~h}$, and the expression of p-mTOR, mTOR, p-AKT, AKT, PDCD4 and $\beta$-actin was detected by western blot analysis. (B) Quantitative analysis of the ratios of p-mTOR/mTOR, p-AKT/AKT and PDCD4/ $\beta$-actin by measuring the relative band density in (B) Ishikawa and (C) HEC-1-A cells. (D) The effect of MK2206 (AKT inhibitor) on the expression of p-mTOR, mTOR, p-AKT, AKT, PDCD4 and $\beta$-actin in Ishikawa and HEC-1-A cells. Cells were pre-treated with $100 \mathrm{nM}$ of MK2206 for $2 \mathrm{~h}$, and then treated with $10 \mu \mathrm{M}$ of progesterone (P4) for $4 \mathrm{~h}$, and the expression of p-mTOR, mTOR, p-AKT, AKT, PDCD4 and $\beta$-actin was detected by western blot analysis. (E) Quantitative analysis of the ratios of p-mTOR/mTOR, p-AKT/AKT and PDCD4/ $\beta$-actin by measuring the relative band density in (E) Ishikawa and (F) HEC-1-A cells. ${ }^{*} \mathrm{P}<0.05$ vs. the control group ( $\mathrm{P} 4$ only) ${ }^{* *} \mathrm{P}<0.01$ vs. the control group ( $\mathrm{P} 4$ only); ns, not significant; $\mathrm{P} 4$, progesterone.

AKT inhibitor (MK2206) to pretreat Ishikawa and HEC-1-A cells for $2 \mathrm{~h}$ (Fig. 5D-F), respectively, and then progesterone (P4) was administered. The results showed that the expression of p-AKT was significantly lower $(\mathrm{P}<0.05)$ and the expression of PDCD4 was significantly increased $(\mathrm{P}<0.05)$ in both cell lines when compared with $\mathrm{P} 4$ treatment alone, while the expression of $\mathrm{p}$-mTOR exhibited no obvious changes $(\mathrm{P}>0.05)$ in Ishikawa and HEC-1-A cells (Fig. 5).

\section{Discussion}

PDCD4, as a tumor suppressor, regulates the expression of various genes related to tumor development and progression at the transcriptional and translational levels. PDCD4 was found to be decreased or lost in different types of cancer, including liver and lung cancer. The expression of PDCD4 is regulated by various factors, such as apoptosis inducers and cytokines. We previously found that PDCD4 expression was significantly decreased in the progesterone-predominated secretory phase of the normal endometrium compared with that in estrogen-predominated proliferative phase (17), which suggests that PDCD4 expression is hormonally regulated in the human endometrium.

The human endometrium is composed of epithelial and stromal cells, and it is cyclically regenerated. The reproductive cycle is induced by neuroendocrine signaling (20). The endometrium is driven into the proliferative phase of the cycle by increased estrogen, and then progesterone is produced by the ovary. The progesterone inhibits proliferation of the endometrium and drives the endometrium into a secretory phase in anticipation of fertilization (20). However, if there is no fertilization, the endometrium is shed and hormone 
levels are decreased, and then the cycle is reactivated $(21,22)$. As well known, prolonged exposure to estrogen is a major endocrine risk factor for the establishment and progression of various diseases, such as endometriosis (23) and endometrial carcinoma (24). Progesterone counteracts estrogen-mediated action and exhibits anti-proliferative and anti-inflammatory roles $(25-27)$. Therefore, the antagonistic nature of progesterone to estrogen in the endometrium empowers progesterone as the first-line of hormonal therapy for the clinical treatment of endometriosis (28-31) and endometrial carcinoma. However, the therapeutic efficacy and beneficial effect of progesterone on the pathogenesis of endometrial carcinoma remain debatable (32). In the present study, it was demonstrated that progesterone downregulates PDCD4 protein expression, which suggests that PDCD4 is a progesterone target gene. Considering that PDCD4 is a type of tumor suppressor, which inhibits tumor development and progression, downregulation of PDCD4 by progesterone may be one of the reasons that progesterone has limited therapeutic efficacy.

Classically, the actions of progesterone are attributed to the binding of progesterone and nuclear progesterone receptor (nPR) and subsequent activation of its downstream target genes (33). In addition, cell membrane hormonal receptors, such as the membrane progesterone receptor (mPR) family, have been identified and demonstrated to be functional (34-37). mPR is able to activate the MAPK/ERK and $\mathrm{PI} 3 \mathrm{~K} / \mathrm{AKT}$ pathways, which also leads to regulation of gene expression (38). Mammalian target of rapamycin (mTOR) is a target gene of PI3K/AKT. It has been reported that miR-21 inhibits PDCD4 expression and activates the PI3K/AKT/mTOR signaling pathway (39). Dorrello et al (40) revealed a new signaling branch of the mTOR pathway that controls the degradation of PDCD4. In the present study, it was demonstrated that $\mathrm{p}$-AKT and p-mTOR were increased and PDCD4 was decreased after treatment of progesterone. Inhibition of PI3K/AKT by LY294002/MK2206 reduced the expression of $\mathrm{p}-\mathrm{AKT}$ and upregulated the expression of PDCD4 protein, while expression of $\mathrm{p}-\mathrm{mTOR}$ exhibited no obvious changes. These results suggest that the PI3K/AKT pathway is involved in progesterone-induced PDCD4 protein downregulation.

In conclusion, it was demonstrated for the first time that progesterone effectively decreases the expression of PDCD4 protein, and the PI3K/AKT pathway may be involved in the downregulation of PDCD4 protein. These results suggest that the downregulation of PDCD4 induced by progesterone could affect the therapeutic efficacy of progesterone in human endometrial cancer or endometriosis, which may have important implications for progesterone treatment in the clinic.

\section{Acknowledgements}

Not applicable.

\section{Funding}

The present study was supported by grants from the National Natural Science Foundation of China (81471437, 81771554), Natural Science Foundation of Shandong (ZR2018MH013), Science and Technology Development Plan provided by the Health and Family Planning Committee in Shandong (2014-25).

\section{Availability of data and materials}

The datasets used during the present study are available from the corresponding author upon reasonable request.

\section{Authors' contributions}

ZW designed the research project and conducted the experimental study. XiaW participated in designing the experiments, writing and reviewing the manuscript. XisW performed the experiments and wrote the manuscript. YueL was involved in performing various experiments. LW and YaL were involved in statistical analysis. YSu and YuqL participated in preparation of the manuscript. YSh and LZ were involved in revising it critically for important intellectual content. HZ and JW assisted in data analysis and reviewing the manuscript. All authors read and approved the final manuscript and agree to be accountable for all aspects of the research in ensuring that the accuracy or integrity of any part of the work are appropriately investigated and resolved.

\section{Ethics approval and consent to participate}

Not applicable.

\section{Patient consent for publication}

Not applicable.

\section{Competing interests}

None of the authors has any potential financial conflicts of interests related to this manuscript.

\section{References}

1. Cmarik JL, Min H, Hegamyer G, Zhan S, Kulesz-Martin M, Yoshinaga H, Matsuhashi S and Colburn N: Differentially expressed protein Pdcd4 inhibits tumor promoter-induced neoplastic transformation. Proc Natl Acad Sci USA 96: 14037-14042, 1999.

2. Yang HS, Jansen AP, Nair R, Shibahara K, Verma AK, Cmarik JL and Colburn NH: A novel transformation suppressor, Pdcd4, inhibits AP-1 transactivation but not NF-kappaB or ODC transactivation. Oncogene 20: 669-676, 2001.

3. Ding L, Zhang X, Zhao M, Qu Z, Huang S, Dong M and Gao F: An essential role of PDCD4 in progression and malignant proliferation of gastrointestinal stromal tumors. Med Oncology 29: 1758-1764, 2012.

4. LaRonde-LeBlanc N, Santhanam AN, Baker AR, Wlodawer A and Colburn NH: Structural basis for inhibition of translation by the tumor suppressor Pdcd4. Mol Cell Biol 27: 147-156, 2007.

5. Lankat-Buttgereit B and Goke R: Programmed cell death protein 4 (pdcd4): A novel target for antineoplastic therapy? Biol Cell 95: 515-519, 2003.

6. Zhang H, Ozaki I, Mizuta T, Hamajima H, Yasutake T, Eguchi Y, Ideguchi H, Yamamoto $\mathrm{K}$ and Matsuhashi S: Involvement of programmed cell death 4 in transforming growth factor-beta1-induced apoptosis in human hepatocellular carcinoma. Oncogene 25: 6101-6112, 2006.

7. Chen Y, Knosel T, Kristiansen G, Pietas A, Garber ME, Matsuhashi S, Ozaki I and Petersen I: Loss of PDCD4 expression in human lung cancer correlates with tumour progression and prognosis. J Pathol 200: 640-646, 2003. 
8. Wen YH, Shi X, Chiriboga L, Matsahashi S, Yee $\mathrm{H}$ and Afonja $\mathrm{O}$ Alterations in the expression of PDCD4 in ductal carcinoma of the breast. Oncol Rep 18: 1387-1393, 2007.

9. Wei NA, Liu SS, Leung TH, Tam KF, Liao XY, Cheung AN, Chan KK and Ngan HY: Loss of programmed cell death 4 (Pdcd4) associates with the progression of ovarian cancer. Mol Cancer 8: 70, 2009.

10. Shibahara K, Asano M, Ishida Y, Aoki T, Koike T and Honjo T: Isolation of a novel mouse gene MA-3 that is induced upon programmed cell death. Gene 166: 297-301, 1995.

11. Lankat-Buttgereit B and Goke R: The tumour suppressor Pdcd4: Recent advances in the elucidation of function and regulation. Biol Cell 101: 309-317, 2009.

12. Onishi Y and Kizaki H: Molecular cloning of the genes suppressed in RVC lymphoma cells by topoisomerase inhibitors. Biochem Biophysical Res Commun 228: 7-13, 1996.

13. Azzoni L, Zatsepina O, Abebe B, Bennett IM, Kanakaraj P and Perussia B: Differential transcriptional regulation of CD161 and a novel gene, 197/15a, by IL-2, IL-15, and IL-12 in NK and T cells. J Immunol 161: 3493-3500, 1998.

14. Mundim TC, Ramos AF, Sartori R, Dode MA, Melo EO, Gomes LF, Rumpf R and Franco MM: Changes in gene expression profiles of bovine embryos produced in vitro, by natural ovulation, or hormonal superstimulation. Genet Mol Res 8: 1398-1407, 2009.

15. Qin X, Zhang H, Wang F, Xue J and Wen Z: Expression and possible role of interleukin-10 receptors in patients with adenomyosis. Eur j Obstet Gynecol Rep Biol 161: 194-198, 2012.

16. Lin SL, Yan LY, Zhang XT, Yuan J, Li M, Qiao J, Wang ZY and Sun QY: ER-alpha36, a variant of ER-alpha, promotes tamoxifen agonist action in endometrial cancer cells via the MAPK/ERK and PI3K/Akt pathways. PLoS One 5: e9013, 2010.

17. Liu Y, Tan X, Wang Z, Li Y, Gao M, Li Y, Fang Z, Sun Y, Zhang L, Wang $X$ and Wei Z: Down-regulation of tumo suppressor PDCD4 expression in endometrium of adenomyosis patients. Curr Res Transl Med 64: 123-128, 2016.

18. Li N, Wang J, Zhang N, Zhuang M, Zong Z, Zou J, Li G, Wang X, Zhou H, Zhang L and Shi Y: Cross-talk between TNF- $\alpha$ and IFN- $\gamma$ signaling in induction of B7-H1 expression in hepatocellular carcinoma cells. Cancer Immunol Immunother 271-283, 2018.

19. Pant A, Lee II, Lu Z, Rueda BR, Schink J and Kim JJ: Inhibition of AKT with the orally active allosteric AKT inhibitor, MK-2206, sensitizes endometrial cancer cells to progestin. PLoS One 7: e41593, 2012.

20. Nabilsi NH, Broaddus RR, McCampbell AS, Lu KH, Lynch HT, Chen LM and Loose DS: Sex hormone regulation of survivin gene expression. J Endocrinol 207: 237-243, 2010.

21. Bischof P, Krahenbuhl C and Desaulles PA: Elucidation of the mechanism responsible for the luteolytic effect of oestradio during pseudogestation in the rat. Experientia 30: 1101-1102, 1974.

22. Knobil E: Hormonal control of the menstrual cycle and ovulation in the rhesus monkey. Acta Endocrinol Suppl (Copenh) 166 137-144, 1972

23. Zhao Y, Gong P, Chen Y, Nwachukwu JC, Srinivasan S, Ko C, Bagchi MK, Taylor RN, Korach KS, Nettles KW, et al: Dual suppression of estrogenic and inflammatory activities for targeting of endometriosis. Sci Transl Med 7: 271ra9, 2015.

24. Stadel BV: Estrogen therapy and endometrial carcinoma. Am J Obstet Gynecol 125: 571-573, 1976.
25. Fang Z, Yang S, Lydon JP, DeMayo F, Tamura M, Gurates B and Bulun SE: Intact progesterone receptors are essential to counteract the proliferative effect of estradiol in a genetically engineered mouse model of endometriosis. Ferti Steril 82: 673-678, 2004.

26. Cooke PS, Buchanan DL, Young P, Calhaz-Jorge C, D'Hooghe T, De Bie B, Heikinheimo O, Horne AW, Kiesel L and Nap A: Stromal estrogen receptors mediate mitogenic effects of estradiol on uterine epithelium. Proc Natl Acad Sci USA 94: 6535-6540, 1997.

27. Li Y, Adur MK, Kannan A, Davila J, Zhao Y, Nowak RA, Bagchi MK, Bagchi IC and Li Q: Progesterone alleviates endometriosis via inhibition of uterine cell proliferation, inflammation and angiogenesis in an immunocompetent mouse model. PLoS One 11: e0165347, 2016.

28. Dunselman GA, Vermeulen N, Becker C, Calhaz-Jorge C, D'Hooghe T, De Bie B, Heikinheimo O, Horne AW, Kiesel L, Nap A, et al: ESHRE guideline: Management of women with endometriosis. Hum Reprod 29: 400-412, 2014

29. Mounsey AL, Wilgus A and Slawson DC: Diagnosis and management of endometriosis. Am Fam Physician 74: 594-600, 2006.

30. Vercellini P, Vigano P, Somigliana E and Fedele L: Endometriosis: Pathogenesis and treatment. Nat Rev Endocrinol 10: 261-275, 2014.

31. Schweppe KW: Current place of progestins in the treatment of endometriosis-related complaints. Gynecol Endocrinol 6: 22-28, 2001.

32. Ruiz MP, Huang Y, Hou JY, Tergas AI, Burke WM, Ananth CV, Neugut AI, Hershman DL and Wright JD: All-cause mortality in young women with endometrial cancer receiving progesterone therapy. Am J Obstet Gynecol 217: 669.e1-669.e13, 2017.

33. Xie M, Zhu X, Liu Z, Shrubsole M, Varma V, Mayer IA, Dai Q, Chen Q and You S: Membrane progesterone receptor alpha as a potential prognostic biomarker for breast cancer survival: A retrospective study. PLoS One 7: e35198, 2012.

34. Thomas P: Characteristics of membrane progestin receptor alpha (mPRalpha) and progesterone membrane receptor component 1 (PGMRC1) and their roles in mediating rapid progestin actions. Front Neuroendocrinol 29: 292-312, 2008.

35. Dressing GE and Thomas P: Identification of membrane progestin receptors in human breast cancer cell lines and biopsies and their potential involvement in breast cancer. Steroids 72: 111-116, 2007.

36. Sleiter N, Pang Y, Park C, Horton TH, Dong J, Thomas P and Levine JE: Progesterone receptor A (PRA) and PRB-independent effects of progesterone on gonadotropin-releasing hormone release. Endocrinology 150: 3833-3844, 2009.

37. Zhu Y, Rice CD, Pang Y, Pace M and Thomas P: Cloning, expression, and characterization of a membrane progestin receptor and evidence it is an intermediary in meiotic maturation of fish oocytes. Proc Natl Acad Sci USA 100: 2231-2236, 2003.

38. Piasecka D, Skladanowski AC, Kordek R, Romanska HM and Sadej R: Aspects of progesterone receptor (PR) activity regulation-impact on breast cancer progression. Postepy Biochem 61: 198-206, 2015

39. Jiang LP, He CY and Zhu ZT: Role of microRNA-21 in radiosensitivity in non-small cell lung cancer cells by targeting PDCD4 gene. Oncotarget 8: 23675-23689, 2017.

40. Dorrello NV, Peschiaroli A, Guardavaccaro D, Colburn NH, Sherman NE and Pagano M: S6K1- and betaTRCP-mediated degradation of PDCD 4 promotes protein translation and cell growth. Science 314: 467-471, 2006. 